\title{
The Muzakki's Compliance to Pay Income Zakat at the Kelantan Islamic and Malay Customs Council (MAIK): An Analysis of the Influencing Factors
}

\author{
Nur Farhana Mohd Yusoff, Mohd Shukri Hanapi*
}

Centre for Islamic Development Management Studies (ISDEV), Universiti Sains Malaysia, 11800 Pulau Pinang, Malaysia

*Corresponding author: hshukri@usm.my

\begin{abstract}
The obligation to pay income zakat has a significant effect on increasing the total collection of income zakat in Kelantan. Income zakat here refers to zakat that is liable on earnings that include emoluments and other forms of income. The Kelantan Islamic Religion and Malay Customs Council (MAIK) made this mandatory in Kelantan on 16 March 1999. The creation of this fatwa (religious decree) had inadvertently affected the increase in total collection of income zakat in Kelantan. For example, from 2001 to 2013, the percentage of zakat collected had increased to 18.55\%, from 5.98\%. The question is, what are the factors that influence the compliance by the muzakki to pay income zakat at MAIK? This qualitative study used primary and secondary data. The primary data was obtained by distributing questionnaires to respondents, whereas the secondary data was obtained from previous studies and literature reviews related to the compliance to pay income zakat. All the data were analysed using the content analysis method. Lastly, this study found that the factors that influenced the muzakki compliance to pay income zakat at MAIK were factors such as the level of satisfaction, needs of the state, attitude towards the state, facilities, confidence and quality of service.
\end{abstract}

Keywords: Factor; compliance; pay; income zakat; MAIK

\begin{abstract}
Abstrak
Kewajipan menunaikan zakat pendapatan dilihat dapat memberi kesan yang signifikan terhadap peningkatan jumlah kutipan zakat pendapatan di Kelantan. Zakat pendapatan di sini merujuk kepada zakat yang dikenakan terhadap perolehan yang merangkumi pendapatan gaji dan pendapatan bebas. Majlis Agama Islam dan Adat Istiadat Melayu Kelantan (MAIK) telah mewajibkan zakat pendapatan pada 16 Mac 1999. Hal ini sedikit sebanyak telah memberi kesan terhadap peningkatan jumlah kutipan zakat pendapatan di Kelantan. Misalnya, dari tahun 2001 sehingga tahun 2013, peratusan pungutan zakat meningkat sebanyak $18.55 \%$ daripada 5.98\%. Persoalannya, apakah faktor-faktor yang mendorong kepada kepatuhan muzakki membayar zakat pendapatan di MAIK? Justeru, kajian ini bertujuan mengenal pasti dan menganalisis faktor-faktor yang mempengaruhi kepatuhan pembayaran zakat pendapatan di MAIK. Kajian kualitatif ini menggunakan data primer dan data sekunder. Data primer diperoleh daripada pengedaran soal selidik kepada responden, manakala data sekunder diperoleh daripada kajian-kajian dan karya-karya yang berkaitan kepatuhan membayar zakat pendapatan. Semua data ini dianalisis menggunakan analisis kandungan. Akhirnya kajian ini mendapati faktor yang mempengaruhi kepatuhan membayar zakat pendapatan di MAIK ialah faktor tahap kepuasan hati, faktor keperluan negeri, faktor sikap kenegerian, faktor kemudahan, faktor keyakinan dan faktor kualiti perkhidmatan.
\end{abstract}

Kata kunci: Faktor; kepatuhan; membayar; zakat pendapatan; MAIK

(C) 2016 Penerbit UTM Press. All rights reserved

\subsection{INTRODUCTION}

The term income zakat is made up of two words, namely zakat and income. Zakat, from syarak perspective, is a mandatory right on any property (Wahbah al-Zuhaili, 1994:821). Zakat was also defined by the fuqaha' from the various sects, namely Hanafi, Maliki, al-Syafi' 'iy and Hanbali sects. According to al-Hanafiyyah, zakat is the provision of a portion of the wealth owned determined according to a certain rate on a certain amount of wealth for certain people(s) as ascertained by Allah SWT (Wahbah al-Zuhaili, 1994:821). The scholar alMalikiyyah defined zakat as allocating a portion of the property that has fulfilled the nisab to those who have the right to receive it provided the wealth has satisfied the hawl and ownership requirements. Whereas the scholar al-Syafi 'iyyah defined zakat as allocating wealth in a particular manner. Meanwhile, the scholar al-Hanabilah defined zakat as the mandatory right to a specific kind of wealth given to a specific group at a specific time (Zulkifli Mohamad Al-Bakri, 2011).

The word income according to the Inland Revenue Board of Malaysia (2011) refers to wages, emoluments, leave, remuneration, commission, bonuses, rewards, additional payments or allowances in the form of money or otherwise that is related to having or being employed. Employment income that covers all forms of remuneration, including housing, travelling and government allowances, is considered as gross income if it could be shown that these allowances accrued from having or being employed. When the word zakat is combined with the word income, then the word income zakat is formed. Income zakat is also known as the al-mal al-mustafad zakat, which means any reward received from any party as a form of remuneration for specialist work, which is permitted by syarak. According to Mujaini Tarimin (2005:31), there are four characteristics that reflect the policy of the al-mal al-mustafad zakat. First, livestock or 
business products; second, remunerations, rewards or wages and services; third, payments for freelance professional services; and fourth is transferred remuneration.

In Kelantan, the legislation of income zakat has affected in the increase of income zakat's collection and the number of muzakki. In 2013, the number of muzakki in MAIK is a total of 35,722 people. However, apart from these 35,722 muzakki there are also some muzakki that work outside Kelantan's state but still paying their income zakat at MAIK. The question is, why the muzakki that work outside Kelantan's state also contribute towards the collection of income zakat in MAIK while the Selangor Zakat Institution and the Federal Territory Islamic Religious Council thought that income zakat is preferable to be issued to those that work at their area. Infact, the opinion by these two organizations are parallel to the zakat's localisation concept proposed by Muhammad Syukri Salleh (2003). Hence, what are the determinant factors that influence them paying their income zakat at MAIK? Thus, this research paper intends to determine the factors that influence those muzakki that work outside Kelantan's state but paying their income zakat to MAIK.

In order to study the factors, this paper has two objectives. First, to determine the factors that influence the muzakki to pay income zakat at MAIK. Second, to analyse the factors that influence the muzakki to pay income zakat at MAIK. In order to achieve both these objectives, this qualitative study used primary and secondary data. The primary data was obtained by distributing questionnaires to ten (10) respondents; whereas secondary data was obtained from previous studies and literature reviews relevant to the topic of muzakki to pay income zakat. Then, the data were collected and analysed using the content analysis method.

The determinant factors that had been identified in this paper are important because these factors would help the management of MAIK to promote income zakat and also increase the total income zakat collected in Kelantan.

Overall, the discussion in this article is divided into five sections, which comprises income zakat in Kelantan, methodology, the deciding factors that influence the muzakki compliance to pay income zakat at MAIK, findings and discussion and lastly, the conclusion.

\subsection{LITERATURE REVIEW}

\section{Income Zakat in Kelantan}

Income zakat in Malaysia was first received and implemented on 9 December 1992. In 1997, The National Fawta Council agreed that zakat on emoluments is compulsory for those who are able to contribute zakat. Hence, the date of implementation and management of income zakat differs according to each state.

In Kelantan, the Kelantan Islamic Religion and Malay Customs Council (MAIK) administers all matters related to zakat. MAIK is under the auspices of the Kelantan state government and is responsible for managing matters pertaining to zakat. The MAIK Enactment of 1994 states that besides assisting His Highness the Al-Sultan Kelantan, who is the Head of Islam and Malay Customs in the State of Kelantan, MAIK is the highest religious authority that monitors Islamic religious affairs in the state. The jurisdiction granted to MAIK according to Enactment Number 4 of 1994 covers areas such as administrating wills and estates belonging to Muslims in Kelantan as well as being a trustee; second, to manage matters pertaining to contracts and administration of property that belongs to or has interests invested by MAIK including the commercialization of the property according to syarak; third, have the authority to form and manage welfare centres for orphans etc.; fourth, to plan and implement activities that would improve the status of Muslims; fifth, endeavour to develop the socio-economic status of Muslims and members of the Religious Council in an advisor's capacity; sixth, to form corporations in order to initiate, monitor, administer and manage project schemes or enterprises with the approval of His Highness the al-sultan of Kelantan (MAIK, 2014).

The gazetting of mandatory income zakat by MAIK came into effect on 16 March 1999. Pertaining to this gazette, MAIK had registered yearly increases in total zakat collection. The percentage of increase in zakat collection is shown in Table 1.

Table 1 Statistics on Zakat collection for the state of Kelantan

\begin{tabular}{cccc}
\hline Year & Total $(\mathbf{R M})$ & Total Increase (RM) & Change in Increase (\%) \\
\hline $\mathbf{2 0 0 1}$ & $16,557,594$ & 934,456 & 5.98 \\
$\mathbf{2 0 0 2}$ & $16,877.786$ & 320,192 & 1.93 \\
$\mathbf{2 0 0 3}$ & $18,465,929$ & $1,588,143$ & 9.41 \\
$\mathbf{2 0 0 4}$ & $22,383,844$ & $3,917,915$ & 21.22 \\
$\mathbf{2 0 0 5}$ & $29,369,188$ & $6,985,344$ & 31.21 \\
$\mathbf{2 0 0 6}$ & $35,541,858$ & $6,172,670$ & 21.02 \\
$\mathbf{2 0 0 7}$ & $40,631,246$ & $5,089,388$ & 14.32 \\
$\mathbf{2 0 0 8}$ & $58,167,095$ & $17,535,849$ & 43.16 \\
$\mathbf{2 0 0 9}$ & $66,521,905$ & $8,354,810$ & 14.36 \\
$\mathbf{2 0 1 0}$ & $70,373,329$ & $3,851,424$ & 5.79 \\
$\mathbf{2 0 1 1}$ & $94,083,476$ & $23,710.147$ & 33.69 \\
$\mathbf{2 0 1 2}$ & $113,163,005$ & $19,079,529$ & 20.28 \\
$\mathbf{2 0 1 3}$ & $134,150,727$ & $20,987,722$ & 18.55 \\
\hline Source: An excerpt from the Report on Zakat Collection for the State of Kelantan by MAIK
\end{tabular}

Table 1 shows the statistics for zakat collection in Kelantan from 2001 to 2013. Based on Table 1, the percentage of increase in zakat collection is $5.98 \%$ for 2001 and it rose to $18.55 \%$ in 2013 .

The increase in total zakat collection in Kelantan was boosted by the increase in the collection of income zakat. The increase in total zakat collected from 2010 to 2013 in Kelantan is shown in Table 2. 
Table 2 Increase in total income Zakat in kelantan

\begin{tabular}{ccccc}
\hline Year & $\mathbf{2 0 1 0}$ & $\mathbf{2 0 1 1}$ & $\mathbf{2 0 1 2}$ & $\mathbf{2 0 1 3}$ \\
\hline Income Zakat & $34,783,967.44$ & $49,336,159.91$ & $62,670,497.01$ & $74,162,999.43$ \\
Percentage in Increase (\%) & $\mathbf{1 6}$ & $\mathbf{4 2}$ & $\mathbf{2 7}$ & $\mathbf{1 8}$ \\
\hline \multicolumn{2}{c}{ Source: A Progress Report on the Collection and Distribution of Zakat in Kelantan from 2010-2013 }
\end{tabular}

Table 2 shows that the total zakat collection in Kelantan increased from RM 34,783,967.44 in 2010 to RM 74,162,999.43 in 2013. Thus, there was a 53\% increase from 2010 until 2013.

Besides the total income zakat collected in Kelantan, the number of muzakki had also increased. This is clearly evident in Table 3, which shows the number of muzakki according to type of zakat mal for 2010, 2011 and 2012.

Table 3 The Number of Muzakki According to the Type of Zakat Mal for the Year 2010 to 2013

\begin{tabular}{clcccc}
\hline Num. & \multicolumn{1}{c}{ Type of Zakat } & $\mathbf{2 0 1 0}$ & $\mathbf{2 0 1 1}$ & $\mathbf{2 0 1 2}$ & $\mathbf{2 0 1 3}$ \\
\hline $\mathbf{1}$ & Savings Zakat (Zakat Wang Simpanan) & 3,737 & 4,066 & 4,511 & 4,866 \\
$\mathbf{2}$ & Income Zakat (Zakat Pendapatan) & 19,969 & 22,576 & 29,815 & 35,722 \\
$\mathbf{3}$ & Shares Zakat (Zakat Saham) & 124 & 129 & 159 & 169 \\
$\mathbf{4}$ & Business Zakat (Zakat Perniagaan) & 1,341 & 1,488 & 1,752 & 1,874 \\
$\mathbf{5}$ & Gold/Silver Zakat (Zakat Emas/Perak) & 153 & 245 & 427 & 580 \\
$\mathbf{6}$ & Property Zakat (Zakat Harta) & 1,871 & 1,909 & 2,169 & 2,214 \\
$\mathbf{7}$ & Agriculture Zakat (Zakat Pertanian) & 1 & 1 & - & 6 \\
$\mathbf{8}$ & Livestock Zakat (Zakat Ternakan) & 2 & - & 3 & 7 \\
& TOTAL & $\mathbf{2 7 , 1 9 8}$ & $\mathbf{3 0 , 4 1 4}$ & $\mathbf{3 8 , 8 3 6}$ & $\mathbf{4 5 , 4 3 8}$ \\
& & & & \\
\hline
\end{tabular}

Table 3 shows the number of muzakki according to the type of zakat from 2010 until 2013. For 2013 the number of muzakki eligible to pay income zakat increased from 19,969 to 35,722 individuals. The increase in the number of muzakki clearly shows the increase in awareness about paying income zakat in Kelantan.

From the total of 35,722 muzakki that paid income zakat at MAIK, it is finding that there are some muzakki that work outside Kelantan's state but still paying their income zakat at MAIK. Hence, the main objectives of this paper are to find the determinant factors that drive the muzakki to pay income zakat at MAIK and to analyze the factors.

\subsection{METHODOLOGY}

This qualitative study used primary and secondary data. Primary data was obtained by distributing questionnaires to 10 respondents. The researcher used two methods to select the respondents, namely purposive sampling and snowball sampling methods because personal information about income zakat contributors at MAIK is strictly confidential. Therefore, the researcher started by looking for respondents who fitted the main criteria according to purposive sampling, which is the payment of income zakat at MAIK. After the respondents were interviewed, they were asked to name other subjects in the population who possessed the same characteristics. This sampling method is continuously used until the researcher obtains the desired number of respondents. The maximum number of respondents is estimated to be 10 or until the information has reached a saturation point.

Meanwhile, the justification for choosing MAIK as a location of study was based on three reasons. First, the choice of Kelantan or more specifically, MAIK, is because the Kelantan is famous the name of 'Serambi Makkah' (Asiah Ali, 2002) which means that the state is govern by the Islamic ruling. Second, the choice of Kelantan was due to the huge potential that MAIK was able to achieve by collecting income zakat, as Kelantan is one the states with the highest collection of income zakat. Third, Kelantan is different from other states because it has limited financial (Nurul Syahidah Roslan \& Mohd Adib Ismail, 2013). Among the resources of Kelantan is zakat collection, which is used to develop Kelantan.

The secondary data was obtained from researches and literary works that were pertinent to the adherence to pay income zakat. Among them are researches by Sanep Ahmad and Hairunnizam Wahid (2004); Sanep Ahmad (2004); Sanep Ahmad and Hairunnizam Wahid (2005); Sanep Ahmad, Hairunnizam Wahid and Adnan Mohamad (2006); Hairunnizam Wahid, Mohd Ali Mohd Noor, and Sanep Ahmad (2005); Mueller (1986); Sherif and Hovland (1961); and Hairunnizam Wahid, Sanep Ahmad and Mohd Ali Mohd Noor (2007). Whereas, the main literary works used by reseachers were those by Wahbah al-Zuhaili (1994) and Mujaini Tarimin (2005). Examination of previous research and literary works was performed in order to identify research gaps, determine existing deciding factors related to payment of income zakat and to help the reseacher to analyse these factors. All these data were analysed using the content analysis method. 


\subsection{FINDINGS AND DISCUSSION}

\section{The Deciding Factors That Influence the Muzakki to Pay Income Zakat at MAIK}

This study used questionnaires to determine the deciding factors that influence the muzakki to pay income zakat at MAIK, besides some of the factors mentioned in previous researches and literature reviews. Among the deciding factors that were identified from previous researches and literature reviews were the intrinsic and extrinsic factors. The intrinsic factors comprise the intentions and attitude; whereas the extrinsic factors comprise the level of satisfaction, facilities, service quality and exposure to promotions about zakat.

Through these questionnaires, the respondents were requested to list down at least two main factors that drives them to pay income zakat at MAIK according to priority. There was one other deciding factor that was identified besides the factors mentioned in previous researches and literature reviews, which was the "needs of the state' $(n=5,25 \%)$ and categorized as an extrinsic factor. This 'needs of the state' factor means that the muzakki felt that Kelantan is one of the states that still needs financial assistance and zakat is essential for the development of Kelantan. The deciding factors that influence the muzakki to pay income zakat at MAIK are shown in Table 4.

Table 4 The Deciding Factors that Influence the Muzakki to Pay Income Zakat at MAIK

\begin{tabular}{|c|c|c|c|c|c|c|c|c|c|c|c|c|}
\hline \multirow[t]{2}{*}{ Num. } & \multirow[t]{2}{*}{ Factors } & \multicolumn{10}{|c|}{ Respondents } & \multirow[t]{2}{*}{ Total } \\
\hline & & R1 & $\mathbf{R 2}$ & R3 & R4 & R5 & R6 & R7 & R8 & R9 & R10 & \\
\hline 1 & Level of Satisfaction (Tahap Kepuasan Hati) & $\bullet$ & & & $\bullet$ & $\bullet$ & $\bullet$ & & $\bullet$ & $\bullet$ & & 6 \\
\hline 2 & Needs of the State (Keperluan Negeri) & & & $\bullet$ & $\bullet$ & & $\bullet$ & & $\bullet$ & - & & 5 \\
\hline 3 & Provincial Attitude (Sikap Kenegerian) & & $\bullet$ & & & $\bullet$ & & & & & & 2 \\
\hline 4 & Facilities (Kemudahan) & & $\bullet$ & $\bullet$ & & & & & & & $\bullet$ & 3 \\
\hline 5 & Quality of Service (Kualiti perkhidmatan) & $\bullet$ & & & & & & $\bullet$ & & & & 2 \\
\hline 6 & Confidence (Keyakinan) & & & & & & & $\bullet$ & & & $\bullet$ & 2 \\
\hline
\end{tabular}

Note: R refers to 'respondent'; R1 refers to the first respondent; R2 refers to the second respondent; R3 refers to the third respondent; R4 refers to the fourth respondent; R5 refers to the fifth respondent; R6 refers to the sixth respondent; R7 refers to the seventh respondent; R8 refers to the eight respondent; R9 refers to the ninth respondent and $\mathrm{R} 10$ refers to the tenth respondent.

Table 4 shows the deciding factors that influence the muzakki to pay income zakat at MAIK. The extrinsic factors comprised 'the level of satisfaction' $(n=6,30 \%)$, 'needs of the state' $(n=5,25 \%)$, 'facilities' $(n=3,15 \%)$ and 'quality of service' $(n=2,10 \%)$. Whereas the intrinsic factors comprised the 'statehood attitude' $(\mathrm{n}=2,10 \%)$ and 'confidence' $(\mathrm{n}=2,10 \%)$ factors.

This section will look into the analysis of the muzakkis' views about the deciding factors that influence their compliance to pay income zakat at MAIK. These deciding factors comprised 'the level of satisfaction', 'needs of the state', 'statehood attitude', 'facilities', 'confidence' and 'quality of service'.

\section{a) The Level of Satisfaction Factor}

Based on the questionnaire given out to the ten respondents, six respondents $(60 \%)$ stated that the 'level of satisfaction' factor had driven them to pay income zakat at MAIK. They were also very satisfied with the method of distributing the zakat introduced by MAIK, which is called the wa' ad method

The wa'ad method gives the right to the muzakki to self-distribute a portion of their zakat to Muslims who fall into the eight groups that are eligible to receive zakat. According to this method, MAIK allows 25 percent (one quarter) of the total zakat paid to MAIK to be self-distributed by the muzakki to the group involved via a written agreement. This initiative was taken to enhance the level of satisfaction of the muzakki regarding zakat distribution in MAIK. Regarding the 'level of satisfaction' factor, R1 in this study mentioned that:

"MAIK allows self-distribution of zakat funds to the poor and needy. I can ask from MAIK as much as $1 / 4$ of the zakat I paid to MAIK to be distributed by myself to the poor and needy in my village in Kelantan. This is very helpful. Previously, self-distributed zakat to the poor and needy was not eligible for rebate because there was no receipt given." (R1)

This matter was also emphasised by five other respondents, namely R4, R5, R6, R8 and R9. This means that the method of distributing zakat introduced by MAIK, which is the wa'ad method, has succeeded in enhancing the muzakkis' level of satisfaction.

The 'level of satisfaction' factor, which is presumed to be the dominant factor that influences the muzakki, is in line with researches carried out by Sanep Ahmad and Hairunnizam Wahid (2004); Sanep Ahmad (2004); Sanep Ahmad and Hairunnizam Wahid (2005); Sanep Ahmad, Hairunnizam Wahid and Adnan Mohamad (2006); and Hairunnizam Wahid, Mohd Ali Mohd Noor, Sanep Ahmad (2005).

Research carried out by Sanep Ahmad and Hairunnizam Wahid (2004); and Sanep Ahmad (2004) found that the feeling of satisfaction towards the efficiency of the zakat centre management, especially when the zakat institution is able to effectively distribute zakat, is an important factor that influences the compliance to pay zakat at a formal institution. The zakat distribution aspect is the most important aspect because it shows how the zakat fund lends effect to society and the nation in reference to the eradication of poverty and economic development. This is because the zakat distribution aspect ensures the decrease in the number of the needy and poverty-stricken (Sanep Ahmad and Hairunnizam Wahid, 2005).

When many zakat payees are not satisfied with the method of distribution implemented by the zakat institution, it would cause the payee to fulfil his responsibility directly to the individual eligible to receive zakat without going through the zakat institution (Sanep Ahmad, 
Hairunnizam Wahid and Adnan Mohamad, 2006). According to Hairunnizam Wahid, Mohd Ali Mohd Noor and Sanep Ahmad (2005), the 'satisfaction of zakat distribution by the zakat institution' factor is very significant in influencing the compliance to pay zakat. The study found that if the level of 'satisfaction with zakat distribution' increased by one unit, the individual's readiness to pay zakat at a formal institution increased by $44.5 \%$. Conversely, if the zakat payee is not satisfied with the zakat distribution then the probability of not paying zakat was at $55.5 \%$. This shows that the 'satisfaction with zakat distribution' aspect is an important aspect that influences zakat payment.

This also proves that the muzakki who pay income zakat at MAIK prefer to distribute their zakat personally instead of wholly surrendering the responsibility to MAIK so that they would eventually be satisfied with the zakat distribution. This is stated by R9, as shown below.

"I can personally distribute the $25 \%$ of zakat paid to MAIK. Many people that I know personally are still poor.

Thus, I can help in some way the poor that I know" (R9)

This matter was also adduced by R1, R5 and R8, whereby the wa 'ad method give them some satisfaction because they are able to distribute themselves the $25 \%$ of their income zakat to the group entitled to receive zakat that they know personally.

\section{b) Needs of the State}

The 'needs of the state' factor was identified through questionnaires filled by the respondents because as far as examining previous researches and literature reviews, the 'needs of the state' factor has not been researched of reviewed.

According to the questionnaires distributed to respondents, five (50\%) out of the ten (10) respondents stated that the factor that drove them to pay income zakat at MAIK was the 'needs of the state' factor. This is because they feel that Kelantan is a state that is still at a stage where it needs financial assistance. Among the respondents who stated that the 'needs of the state' factor had influenced their choice of payment to be at MAIK was R3. R3 stated that:

"Kelantan still needs help and is among the states that is still at the stage of needing help based on my knowledge of the situation." (R3)

This view was also expressed by R4, R6, R8 and R9 in this study. The respondent's statements show that the Statistics for Population Distribution of Hard-Core Poor in Kelantan comprises 2,728 households that are still registered as hard-core poor in Kelantan (e-Tegar).

\section{c) Attitude towards the State}

The questionnaires indicated that only two (20\%) out of ten respondents stated that they pay income zakat at MAIK because they were driven by the 'provincial attitude' factor. This attitude is an intrinsic factor, which is usually influenced by the intention to help the birth state of the respondent.

According to Mueller (1986), attitude plays an important role in influencing a person when making decisions. This was supported by TGT by placing attitude as one of the important components for predicting the behaviour of a person (Elliot et al., 1999). Sherif and Hovland (1961) stated that the three degrees or latitudes in the latitude theory together create the full spectrum of an individual's attitude. Hence, a person could either accept or reject an issue or could primarily be indifferent to a range of viewpoints. According to Ajzen (1991:188), 'attitude towards behaviour' is defined as the degree of evaluation of whether the person is good or otherwise according to certain behaviour. The trust that outlines an individual's attitude is known as trusting behaviour.

Therefore, compliance to the fatwa on remuneration needs a positive attitude among the members of society towards the zakat institution and the fatwa on remuneration zakat. This is because the assessment system in Malaysia depends fully on the trustworthy characteristics of members of the Islamic community in voluntarily complying with the fatwa on zakat (Kamil Md Idris, 2009:54).

The questionnaire also showed that according to the statements of R2 and R5 the researcher could determine that the 'statehood attitude' factor had influenced them.

\footnotetext{
"I wish to help the state of my birth. The zakat in Kelantan is not much compared to other states because many Kelantenese are working outside Kelantan.”(R2)

"I wish to help the state to prove my loyalty to my state of birth and origin because the zakat in Kelantan is not much as in other states as many Kelantanese are working outside of Kelantan.” (R5)
}

According to the statements by R2 and R5, the researcher's analysis shows that the 'provincial attitude' factor is reflected in the statements because R2 and R5 had paid income zakat at MAIK since MAIK was situated in their state of birth. R2 and R5 had not been objective when choosing to pay their income zakat in Kelantan.

Therefore, it could be concluded that the 'provincial attitude' factor had influenced the respondents to pay income zakat at MAIK because the respondents believed that their actions would help maintain their loyalty to their state of birth. Besides that, they could help their state of birth from a financial perspective.

\section{d) Facilities}

The respondent's decision to pay income zakat at MAIK was also influenced by the 'facilities' factor. According to the questionnaire, three (30\%) out of ten (10) respondents acknowledged that the 'facilities' factor had influenced them. The 'facilities factor is very significant in influencing the income zakat payee because an easier mechanism for Muslims to pay zakat would see a higher zakat collection, especially income zakat (Hairunnizam Wahid, Sanep Ahmad \& Mohd Ali Mohd Noor, 2007). 
There are numerous types of facilities offered by MAIK for the muzakki to pay income zakat such as online payment through internet banking and using credit cards or the Financial Process Exchange (FPX). In this study, the 'online payment facility' factor had influenced the muzakki to choose the option to pay income zakat at MAIK because the respondents were working professionals from the private and public sector and they are committed to their jobs. Hence, the online payment facility would make it easier for them to deal with the MAIK management.

Nevertheless, the facilities factor would not influence the muzakki to pay income zakat at MAIK without the other main factors. This is because the State Islamic Religious Councils in other states also offer similar facilities as MAIK. The three (3) respondents had stated that the 'facilities' factor was only a contributing factor and this is shown in Table 5.

Table 5 The facility factor as a mitigating factor

\begin{tabular}{|c|c|c|c|c|}
\hline Num. & Respondents & $\begin{array}{c}\text { Influencing Factor(s) } \\
\text { According to Importance }\end{array}$ & Reason(s) & Deciding Factor(s) \\
\hline \multirow[t]{2}{*}{$\overline{1}$} & $\mathrm{R} 2$ & i) Help the State & $\begin{array}{l}\text { Zakat for Kelantan is lesser compared to } \\
\text { other states because many Kelantanese } \\
\text { work outside the state. }\end{array}$ & $\begin{array}{l}\text { 'provincial } \\
\text { attitude' }\end{array}$ \\
\hline & & $\begin{array}{l}\text { ii) It is easy because the } \\
\text { records are in MAIK. }\end{array}$ & $\begin{array}{l}\text { The information is in MAIK's system. } \\
\text { Hence, it is easier for me to pay; } \\
\text { moreover, it can be done online. }\end{array}$ & 'Facilities' \\
\hline \multirow[t]{2}{*}{2} & R3 & $\begin{array}{l}\text { i) Kelantan still needs } \\
\text { assistance }\end{array}$ & $\begin{array}{l}\text { Among the states that still require } \\
\text { assistance. }\end{array}$ & $\begin{array}{l}\text { 'Needs of the } \\
\text { State' }\end{array}$ \\
\hline & & ii) Facilities & The online payment method is easy. & 'Facilities' \\
\hline \multirow[t]{2}{*}{3} & $\mathrm{R} 10$ & $\begin{array}{l}\text { i) I am confident MAIK is } \\
\text { efficient. }\end{array}$ & $\begin{array}{l}\text { Because I am confident, MAIK is } \\
\text { efficient and fair in distributing zakat. } \\
\text { Hence, I pay at MAIK. There are some } \\
\text { states that I am not confident in with } \\
\text { their management of zakat. }\end{array}$ & 'Confident' \\
\hline & & ii) Online payment facilities & $\begin{array}{l}\text { It is easy for me to pay because there are } \\
\text { online services available. }\end{array}$ & 'Facilities' \\
\hline
\end{tabular}

Table 5 shows the 'facilities' factor as an incidental factor. For example, the second respondent (R2) chose MAIK because of the 'statehood attitude' factor as the main factor and the 'facilities' factor as the incidental factor. The third respondent (R3) stated that the choice of paying zakat at MAIK was due to the 'needs of the state' factor as the main factor and the 'facilities' factor as an incidental factor. So too with the tenth respondent (R10), whereby the 'facilities' factor was the incidental factor and the 'confidence' factor was the main factor.

Therefore, the 'facilities' factor has also contributed to the increase in collection of total income zakat at MAIK because this factor is also one of the reasons why the respondents had chosen MAIK to pay their income zakat.

\section{e) Quality of Service}

After distributing the questionnaires to respondents it was found that only two (20\%) out of the 10 respondents had stated that the 'quality of service' factor had influenced them to pay income zakat at MAIK. R1 had commented about the quality of service factor as follows:

"I feel comfortable with the MAIK management. In my opinion, the zakat management in MAIK are clientfriendly. I am more comfortable with the management in MAIK, especially the zakat office Ustaz Murtadha and the other staffs. They are not only friendly but very helpful too."(R1)

A similar opinion was shared by R7:

“The MAIK management always ensure that MAIK's financial management is well implemented.” (R7)

Although R1 and R7 mentioned that the 'quality of service' factor had influenced their choice to pay income zakat in MAIK; hence, the findings show that the 'quality of service' factor did not influence other respondents to pay zakat at MAIK. This shows that the quality of service rendered by MAIK is deficient. Hence, MAIK should take the initiative to improve the quality of service in order to attract more muzakki to pay income zakat at MAIK. According to Kamil Md. Idris (2009:47), the quality of service offered by zakat institutions would attract the attention of people towards paying zakat. As the positive perception of people towards the quality of service increases, the inclination for them to pay zakat would be high.

A better quality of service is in line with the role of a zakat institution as being an Islamic financial institution. A good and efficient management system would turn the zakat institution into a financial institution that is trusted and admired by society (Azninainie Mohd Ghazi, Sanep Ahmad \& Hairunnizam Wahid, 2013).

\section{f) Confidence}

The confidence factor is closely related to the satisfaction factor. This is because if the zakat payees were not satisfied with the distribution of zakat initiated by the zakat institution then this would cause their confidence towards the institution to wane (Hairunnizam Wahid, Sanep Ahmad \& Radiah Abdul Kader, 2010). 
In this study, two out of the twenty (20\%) respondents stated that they were influenced by the 'confidence' factor to pay income zakat at MAIK. The two (2) respondents were namely respondents seven (R7) and ten (R10). The statements by these respondents are as follows:

"I was influenced by the confidence factor. Confidence on the management of zakat finances by MAIK" (R7)

"I am confident that MAIK is efficient and fair in distributing zakat. Hence, that is why I pay zakat at MAIK.

There are some states that I am not confident in their management of zakat" (R10)

Both the respondents stated that they were confident with MAIK's management of zakat. Indirectly this study compliments studies carried out by Azninainie Mohd Ghazi, Sanep Ahmad and Harirunnizam Wahid (2013). Azninainie Mohd Ghazi, Sanep Ahmad and Hairunnizam Wahid (2013) stated that MAIK had efficiently distributed the zakat and was able to eradicate poverty among the society in Kelantan by improving the total collection of zakat and channelling the distribution of funds to those eligible to receive zakat and the poor.

\subsection{CONCLUSION}

The discussion in this article ensures that all the pertinent questions are answered. This means that both the objectives of this study have been accomplished. Thus, based on the findings it could be concluded that the five deciding factors had influenced the muzakki (those obliged to pay zakat) to pay income zakat at MAIK. The factors are the 'level of satisfaction', the 'needs of the state', 'attitude', 'facilities', 'confidence' and 'quality of service' rendered. The findings of this study had provided a positive implication towards the efforts to improve the field of zakat, especially income zakat. In addition, the findings have also contributed to the zakat institution, especially MAIK and the community.

\section{References}

Ajzen, I (1991). The Theory of Planned Behavior. Organizational Behavior and Human Decision, 50(2), 179-211.

Asiah Ali (2002). Peranan Ulama' Dalam Bidang Pendidikan Islam Di Negeri Kelantan: Suatu Kajian Khusus di Antara Tahun 1940 Hingga 1990. Jurnal Tasawwur Islam Pusat Pendidikan Islam, 5(1). Universiti Teknologi Mara, August 2002.

Azizi Yahaya (2006). Menguasai Penyelidikan: Teori, Analisis dan Interpretasi Data. PTS Professional Publication, Kuala Lumpur.

Azninainie Mohd Ghazi, Sanep Ahmad \& Harirunnizam Wahid (2013). Analisis Pengurusan dan Agihan Dana Zakat di Negeri Kelantan, in Prosiding PERKEM VIII, $3,1291-301$.

Chua Yan Piaw (2006). Kaedah dan Statistik Penyelidikan: Kaedah Penyelidikan. Mc Graw Hill, Malaysia.

Hairunnizam Wahid, Mohd Ali Mohd Noor \& Sanep Ahmad (2005). Kesedaran Membayar Zakat: Apakah Faktor Penentunya?. International Journal of Management Studies, 12(2), 171-189.

Hairunnizam Wahid, Sanep Ahmad \& Mohd Ali Mohd Noor (2007). Kesedaran Membayar Zakat Pendapatan Di Malaysia. Islamiyyat, 29(1), 53-70.

Inland Revenue Board of Malaysia (2011). Income. Accessed on 20 November 2014 from http://www.hasil.gov.my/bt_goindex.php?bt_kump=5\&bt_skum=1\&bt_posi $=2 \& b t$ unit $=5000 \& b t$ sequ $=13 \& b t \_l g v=2$

Kamil Md. Idris (2009). Gelagat Kepatuhan Zakat Pendapatan Penggajian. Universiti Utara Malaysia, Kedah.

Kelantan Islamic Religion and Malay Customs Council (MAIK) (2014). Bidang Kuasa MAIK. Accessed on 20 November 2014 from http://www.e-maik.my/v2/ index.php/mengenai-kami/profil-yang-dipertua-maik/15-mengenai-kami/66-bidang-kuasa.html.

Mueller, D.J (1986). Measuring Social Attitudes. Columbia University, Teachers College, New York.

Mujaini Tarimin (2005). Zakat Menuju Pengurusan Profesional. Sanon Printing Corporation Sdn. Bhd., Kuala Lumpur.

Muhammad Syukri Salleh (2003). Lokalisasi Zakat: Satu Cadangan Teoritis in Prosiding Muzakarah Pakar Zakat, 105-117. Economic Faculty, University Kebangsaan Malaysia, Selangor Darul Ehsan.

Nurul Syahidah Roslan \& Mohd Adib Ismail (2013). Pengamalan Ekonomi Islam di Negeri Kelantan, in Prosiding PERKEM VIII, I, $371-382$.

Sanep Ahmad (2004). Kesaksamaan Agihan Sistem Perkongsian Untung Rugi: Analisis Koefisien Gini. International journal of Management Studies, 11(2), 123-135.

Sanep Ahmad \& Hairunnizam Wahid. (2005). Persepsi dan Faktor Penentu Kesedaran Terhadap Perluasan Sumber Zakat Harta Yang Diikhtilaf, Islamiyyat, 27(1), 4565

Sanep Ahmad \& Hairunnizam Wahid (2005). Persepsi Agihan Zakat dan Kesannya Terhadap Pembayaran Zakat Melalui Institusi Formal. Jurnal Ekonomi Malaysia, $39,53-69$

Sanep Ahmad, Hairunnizam Wahid \& Adnan Mohamad (2006). Penswastaan Institusi Zakat dan Kesannya Terhadap Pembayaran Secara Formal di Malaysia. International Journal of Management Studies, 13(2), 175-196.

Sherif, M., \& Hovland, C.I (1961). Social Judgement: Assimilation and Contrast Effects in Communication and Attitude Change. Yale University Press, New Haven. Wahbah al-Zuhaili (1994). Fiqh \& Perundangan Islam, Jilid IV. (Translation by Md. Akhir Haji Yaacob et al.). Kuala Lumpur: Dewan Bahasa dan Pustaka.

Zulkifli Mohamad Al-Bakri (2011). Fatwa Zakat Kontemporari. Bank Muamalat, Kuala Lumpur. 